\title{
PENGARUH GAYA KEPEMIMPINAN TERHADAP KINERJA KARYAWAN PADA DEPARTEMEN PENGADAAN PT INALUM (Persero)
}

\author{
Soulthan S. Batubara \\ Universitas Pembangunan Pancabudi \\ soulthanbatubara@dosen.pancabudi.ac.id
}

\begin{abstract}
Abstrak
Penelitian ini bertujuan untuk mengetahui pengaruh yang signifikan antara gaya kepemimpinan terhadap kinerja karyawan pada Departemen Pengadaan PT Inalum (Persero).Adapun jenis penelitian yang digunakan adalah metode penelitian kuantitatif. Populasi dalam penelitian ini adalah seluruh karyawan pada Departemen Pengadaan di PT Inalum (Persero) yang berjumlah 36 orang.Sampel dipilih dengan menggunakan metode sensus.Data diolah menggunakan metode uji statistik regresi linear berganda. Hasil penelitian ini membuktikan bahwa gaya kepemimpinan direktif berpengaruh signifikan terhadap kinerja karyawan pada Departemen Pengadaan PT Inalum (Persero). Hal ini dibuktikan dari hasil pengujian parsial yang menunjukkan bahwa variabel gaya kepemimpinan direktif $(\mathrm{X})$ memiliki nilai t-hitung lebih besar dibadingkan t-tabel $(2,748$ $>1,691)$ dengan nilai signifikansi 0,008 ( $\mathrm{Sig}=0,008<0,05)$.
\end{abstract}

Kata Kunci : Gaya Kepemimpinan, Kinerja Karyawan

\section{Abstract}

The study aims to determine the significant influence between the leadership style and the employee's performance at the procurement Department of PT Inalum (Persero). The types of research used are quantitative research methods. The population in this study is all employees of the procurement department at PT Inalum (Persero) which amounted to 36 people. Samples were chosen using the census method. Data is processed using a statistical test method of multiple linear regression. The results of this research proved that the leadership style of the directive has a significant effect on the employee's performance at the procurement Department of PT Inalum (Persero). This is evidenced from the partial test result indicating that the variable leadership style Directive $(X)$ has a larger T-count value in the T-table $(2.748>1.691)$ with a significance value of 0.008 $($ Sig $=0.008<0.05)$.

Keywords: Leadership style, employee performance

\section{PENDAHULUAN}

Pada era globalisasi saat ini, persaingan antar perusahaan semakin tinggi baik industri dagang maupun jasa, sehingga perusahaan perlu meningkatkan performancenya disegala bidang, baik dalam hal peningkatan finansial, sumber daya alam, teknologi dan sumber daya manusia, meski sebuah perusahaan telah memiliki finansial yang kuat, bahan baku yang tersedia, memiliki teknologi yang mutakhir, serta ditunjang dengan sistem manajemen yang baik, jika sumber daya manusianya tidak memadai maka 
e-ISSN 2620-5866

Volume 3. No.1 April 2020 (40-58)

Doi 10.30596/liabilities.v3i1.4581

seluruh faktor produksi tersebut tidak dapat menunjang tercapainya tujuan perusahaan. Hal ini menjadikan Sumber Daya Manusia menjadi salah satu aset terpenting bagi setiap perusahaan (Miftah, 2003), dapat dikatakan bahwa karyawan adalah salah satu faktor penting dalam menentukan terwujudnya tujuan suatu perusahaan. Dalam mewujudkan tujuan yang optimal tentunya perusahaan memerlukan kinerja karyawan.

Proses kegiatan suatu organisasi suatu perusahaan pasti akan mengalami hambatan dan rintangan dalam mencapai tujuannya. Salah satunya adalah upaya dalam peningkatan sumber daya manusia dalam perusahaan atau organisasi. Banyak yang telah mengalami kemunduran bahkan kegagalan dalam mencapai tujuanya hanya karena permasalahan peningkatan sumber daya manusia.

Pola hubungan yang terjadi antara atasan dengan bawahan dapat menyebabkan karyawan merasa senang atau tidak senang bekerja di perusahaan tersebut, untuk itulah dalam organisasi selalu dilakukan perencanaan pengolahan sumber daya manusia untuk mendapatkan orang yang tepat untuk jabatan yang tepat. Salah satu sasaran pengolahan sumber daya manusia pada fungsi manajemen organisasi adalah menyangkut masalah kepemimpinan, seseorang yang ditunjuk sebagai pemimpin maupun yang diakui oleh anggota sebagai orang yang pantas memimpin mereka, dialah yang menjalankan fungsi organisasi tersebut. Cara dan pola tingkah laku pemimpin diartikan oleh bawahan yang berkerjasama dengannya sebagai gaya kepemimpinan.

Kepemimpinan adalah kemampuan untuk memberikan pengaruh yang konstruktif kepada orang lain untuk melakukan satu usaha kooperatif mencapai tujuan yang sudah direncanakan. Selanjutnya menurut Rivai (2005), Kepemimpinan (Leadership) adalah proses mempengaruhi atau memberi contoh kepada pengikut-pengikutnya melalui peroses komunikasi dalam upaya mencapai tujuan organisasi. Seorang pemimpin dalam organisasi harus dapat menciptakan integrasi yang serasi dengan para bawahannya juga termasuk dalam membina kerja sama, mengarah dan mendorong gairah kerja para bawahan sehingga tercipta motivasi positif yang akan menimbulkan niat dan usaha (kinerja) yang maksimal juga didukung oleh fasilitas-fasilitas organisasi untuk mencapai sasaran organisasi. Dimana seorang pemimpin sebagai salah satu bagian dari manajemen memainkan peran yang penting dalam mempengaruhi dan memberikan sikap serta perilaku dan kelompok, sehingga membentuk gaya kepemimpinan yang pemimpin terapkan.

Dapat dipastikan bahwa perilaku seorang pemimpin adalah pengaruh yang akan menimbulkan pemahaman tersendiri yang akan berpengaruh terhadap kondisi psikologis bawahan, ada bawahan yang melihat, mengamati dan meniru perilaku pemimpin yang ditampilkan atasan dirasakan sebagai sesuatu yang diharapkan bawahan maka akan memiliki dampak yang lebih baik terhadap kinerja karyawan, sebaliknya apabila perilaku kepemimpinan yang ditampilkan 
atasan sebagai sesuatu yang tidak sesuai dengan harapannya maka akan berpengaruh kurang baik terhadap kinerja karyawan.

Oleh karena itu untuk meningkatkan kembali kinerja karyawan tersebut, maka salah satu faktor yang perlu diperhatikan adalah menyangkut gaya kepemimpinan yang diterapkan oleh pemimpinpemimpin pada perusahaan yaitu bagaimana agar gaya kepemimpinan yang diterapkan para pemimpin dapat menunjang kinerja karyawannya agar lebih baik. Informasi mengenai gaya kepemimpinan ini penting diketahui oleh pihak perusahaan sendiri karena gaya kepemimpinan merupakan salah satu komponen penting yang akan mempengaruhi kinerja organisasi.

$$
\text { PT Indonesia Asahan }
$$

Aluminium (Inalum), sebuah perusahaan yang bekerjasama antara pemerintah Indonesia dengan Nippon Asahan Aluminium Co, Ltd, didirikan di Jakarta. PT. Inalum adalah perusahaan yang membangun dan mengoperasikan Proyek Asahan, sesuai dengan Perjanjian Induk yang bergerak dalam produksi aluminium.Tantangan utamaPT Inalum (Persero) untuk membangun daya saing yang berkelanjutan terletak pada kompetensi sunberdaya manusianya. Kompetensi manajerial menjadi penting dan mutlak dimiliki oleh setiap SDM, khususnya di departemen pengadaan PT. Inalum (Persero), agar kerumitan menjalankan roda pengelolaan perusahaan dapat ditangani dan diatasi secara benar.

Perusahaan memerlukan good management artinya harus mengembangkan SDM sebagai good manager dan organisasi yang baik. Berbicara soal organisasi, maka ada pihak yang memerintah yang disebut pimpinan yang diperintah/bawahan. Dengan demikian guna meningkatkan profitabilitas perusahaan sangat dipengaruhi oleh kemampuan seorang pemimpin dalam menggerakkan bawahannya untuk bekerja sama dalam melaksanakan tugasanya secara efektif dan efisien. Suatu organisasi akanberhasil atau gagal, tergantung dari gaya kepemimpinan pada para atasannya, yang bertanggung jawab atas pelaksanaan atau pekerjaan dari semua jabatannya yang ada dibawah tanggung jawabnya. Dalam suatu organisasi yaitu perusahaan seorangpemimpin pasti mempunyai gaya kepemimpinan yang berbeda-beda, diantaranya gaya kepemimpinan otokrasi, demokratis dan lain sebagainya.

Semua gaya kepemimpinan
tersebut tidak lepas dari kekurangan dan kelebihan masingmasing, tinggal bagaimana seorang pemimpin menerapkan dalam suatu organisasi perusahaan. Dengan adanya kelemahan dan kekuatan dari gaya tersebut, maka dalam ini penulis mengkhususkan pada gaya kepemimpinan. Gaya kepemimpinan ini merupakan sarana untuk mengarahkan segenap kekuatan dibawahnya sehingga secara bersama-sama mencapai tujuan organisasi efektif dan efisien (Lako, 2004). Untuk mencapai tujuan perusahaan serta meningkatkan produktivitas PT Inalum (Persero) supaya dapat bersaing diperlukan adanya gaya kepemimpinan. Gaya kepemimpinan sangat berpengaruh 
e-ISSN 2620-5866

Volume 3. No.1 April 2020 (40-58)

Doi 10.30596/liabilities.v3i1.4581

terhadap kinerja karyawan, dimana dampak yang terjadi dengan gaya kepemimpinan dapat meningkat dan menurunkan kinerja karyawannya.

Peneliti ketika melakukan studi pendahuluan di bagian Departemen Pengadaan PT Inalum (Persero) dengan memberikan beberapa pernyataan tertulis tentang gaya kepemimpinan kepada karyawan menemukan bahwa gaya kepemimpinan yang dipakai oleh pimpinan bagian Manajemen Sumber Daya Manusia hampir mendekati gaya kepemimpinan direktif. Hal itu terindikasi dari 10 orang yang diberikan pertanyaan ada 7 orang yang menjawab gaya kepemimpinannya dengan jawaban yang menjurus kepada gaya kepemimpinan direktif, itu merupakan dugaan sementara untuk lebih jelasnya peneliti melakukan penelitian terhadap objek yang akan diteliti apabila gaya kepemimpinan di sana menggunakan gaya kepemimpinan direktif maka akan menimbulkan masalah dan dapat mengakibatkan kinerja karyawanmenjadi menurun oleh karena gaya kepemimpinan seperti ini pemimpin berkuasa sepenuhnya terhadap program-program yang akan dibuat dan bawahan wajib mengikuti perintah pemimpin, karyawan tidak dilibatkan dalam penentuan kegiatan dan keputusan akibatnya bawahan menjadi tertekan terhadap kebijakan yang dibuat, rutinitas kerja menjadi membosankan dan bawahan tidak dapat mengembangkan potensi yang dimilikinya.

Secara empiris, terdapat fenomena turnover karyawan yang meningkat dari tahun ke tahunnya di
Departemen Pengadaan PT. Inalum. Berikut adalah data tingkat turnover karyawan pada tahun 2016 hingga 2018:

Tabel 1.1

Tingkat Turnover Karyawan Departemen Pengadaan PT. Inalum 2016-2018

\begin{tabular}{lllll}
\multirow{2}{*}{ Tahun } & \multicolumn{3}{c}{$\begin{array}{c}\text { Jumlah Karyawan } \\
\text { (orang) }\end{array}$} & \multirow{2}{*}{$\begin{array}{c}\text { Turnover } \\
(\%)\end{array}$} \\
\cline { 2 - 5 } & $\begin{array}{c}\text { Awal } \\
\text { Tahun }\end{array}$ & $\begin{array}{c}\text { Akhir } \\
\text { Tahun }\end{array}$ & Resign & \\
\hline 2016 & 41 & 42 & 4 & 9.6 \\
\hline 2017 & 42 & 39 & 6 & 14.8 \\
\hline 2018 & 39 & 36 & 7 & 18.6 \\
\hline
\end{tabular}

Sumber: Departemen Pengadaan PT. Inalum

Berdasarkan Tabel 1.1 dapat dilihat bahwa PT. Inalum (Persero) mengalami tingkat turnover karyawan yang meningkat di setiap tahunnya pada periode 2016-2018. Begitu pula dengan jumlah karyawan yang keluar (resign) dari perusahaan yang meningkat di setiap tahunnya. Pada tahun 2016 tingkat turnover karyawan di level 9,6 persen dan meningkat menjadi 14,8 persen pada tahun 2017 yang selanjutnya pada tahun 2018 mengalami kenaikan lagi menjadi 18,6 persen.

Adapun jumlah karyawan yang keluar (resign) dari perusahaan meningkat dari 4 orang pada tahun 2016 menjadi 6 orang pada tahun 2017 dan kemudian mengalami kenaikan lagi menjadi 7 orang pada tahun 2018. Terkait turnover disarankan tidak lebih besar dari10\% pertahun karena ini mengindikasikan bahaya bagi kelangsungan SDMpada organisasi yang bersangkutan. Sementara itu pada tahun 2017-2018 tingkat turnover karyawan PT. Inalum (Persero) berada di atas angka 
e-ISSN 2620-5866

Volume 3. No.1 April 2020 (40-58)

Doi 10.30596/liabilities.v3i1.4581

$10 \%$, yang artinya melebihi kondisi ideal.

Turnover yang tinggi pada suatu perusahaan menunjukkan perusahaan yang bersangkutan perlu diperbaiki kondisi atau carapembinaannya.Faktor penyebab terjadinya turnover dapat berasal dari faktor gaya kepemimpinan. Ketika karyawan merasa nyaman dengan pemimpin mereka maka karyawan lebih cenderung untuk tinggaldi perusahaan, sebaliknya ketika pemimpin merupakan sumber ketidaknyamanan maka kecenderungan untuk meninggalkan perusahaan akan meningkat.

Gaya kepemimpinan direktif memiliki ciri pemimpin banyak memberi pengarahan dan sedikit memberi dukungan akibatnya kemampuan karyawan tinggi dan kemauannya dalam bekerja menjadi rendah. Kemampuan karyawan tinggi dikarenakan karyawan diberikan tekanan terhadap tugas pekerjaanya yang mengakibatkan adanya unsur keterpaksaan bukan dari kesadaran pribadi karyawan dalam menyelesaikan tugasnya itu. Fenomena peningkatan turnover karyawan yang terjadi bila dikaitkan dengan ciri gaya kepemimpinan direktif menimbulkan indikasi adanya dketidakselarasan dalam pemilihan gaya kepemimpinan yang ideal, dimana seyogianya kepemimpinan yang mumpuni tidak meningkatkan turnoverkaryawan.

\section{Pentingnya}

Dilaksanakan

Penelitian ini dianggap penting untuk dilaksanakan karena hasil penelitian ini dapat membantu pihak Manajemen Departemen Pengadaan PT Inalum (Persero) untuk menganalisis faktor-faktor dominan yang mempengaruhi kinerja karyawan, dimana hasil penelitan tersebut diharapkan mampu menjadi acuan bagi manajemen dalam usaha mengoptimalkan kinerja.

\section{Rumusan Masalah}

Berdasarkan latar belakang yang telah dijabarkan, maka rumusan masalah penelitian ini adalah : Apakah gaya kepemimpinan direktif berpengaruh signfikan terhadap kinerja karyawan pada Departemen Pengadaan PT Inalum (Persero)?

\section{Tujuan Penelitian}

Adapun tujuan yang ingin dicapai dari penelitian ini adalah untuk mengetahui pengaruh yang signifikan antara gaya kepemimpinan direktif terhadap kinerja karyawan pada Departemen Pengadaan PT Inalum (Persero).

\section{Hipotesis Penelitian}

Hipotesis adalah proposisi yang dirumuskan dengan maksud untuk diuji secara empiris yang berupa pernyataan penjelasan jawaban sementara yang dapat dipercaya, disangkal atau diuji kebenarannya. Sebelum dilakukan penarikkan hipotesis penelitian, berikut di gambarkan kerangka konsep penelitian ini :

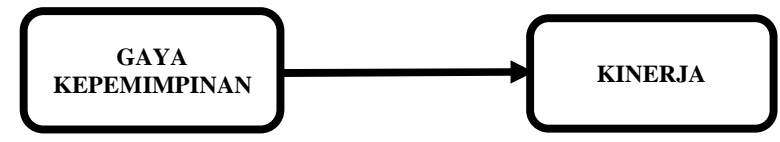

Gambar 1.1

Kerangka Konseptual Penelitian

Berdasarkan perumusan

masalah, tujuan penelitian dan kerangka konsep yang telah diuraikan, maka hipotesis dalam penelitian ini adalah : Kepemimpinan 
e-ISSN 2620-5866

Volume 3. No.1 April 2020 (40-58)

Doi 10.30596/liabilities.v3i1.4581

direktif berpengaruh positif dan signifikan terhadap kinerja karyawan pada Departemen Pengadaan PT Inalum (Persero).

\section{Luaran Penelitian}

Luaran pada penelitian ini terdiri atas luaran wajib. Luaran wajib penelitian ini adalah publikas jurnal ilmiah pada tingkat lokal.

\section{TINJAUAN PUSTAKA \\ Kinerja Karyawan}

Pengertian kinerja atau prestasi kerja diberi batasan oleh maier sebagai kesuksesan seseorang di dalam melaksanakan suatu pekerjaan. Lebih tegas lagi Dessler (2005) menyatakan bahwa kinerja adalah "succesfull role achievment" yang diperoleh seseorang dari perbuatan-perbuatannya. Dari batasan tersebut dapat disimpulkan bahwa kinerja adalah hasil yang dicapai seseorang menurut ukuran yang berlaku untuk pekerjaan yang bersangkutan.

Kinerja mengacu pada kadar pencapaian tugas-tugas yang membentuk pekerjaan seluruh karyawan. Kinerja juga merefleksikan seberapa baik para karyawan memenuhi persyaratan sebuah pekerjaan yang sudah ditentukan oleh perusahaan sesuai dengan bidang kerjanya masingmasing.Kinerja menurut Mangkunegara (2005) bahwa kinerja adalah hasil kerja secara kualitas dan kuantitas yang dicapai oleh seorang karyawandalam melaksanakan tugasnya sesuai dengan tanggung jawab yang dibeikan kepadanya.

Menurut Rivai (2005) kinerja merupakan perilaku nyata yang ditampilkan setiap orang sebagai prestasi kerja yang dihasilkan karyawan sesuai dengan perannnya dalam perusahaan, yang mana kinerja karyawan sangat penting dalam upaya perusahaan untuk mencapai tujuannya. Sedangkan menurut Dale S. Beach seperti yang dikutip Ruky (2001) kinerja adalah sebuah penilaian sistematis atas individu karyawan mengenai prestasi kerjanya dan potensinya untuk pengembangan.

Manullang

(2006)

berpendapat bahwa kinerja adalah hasil kerja seseorang atau kelompok selama periode tertentu dibandingkan dengan berbagai kemungkinan, misalnya standar, target atau kriteria yang telah ditentukan terlebih dahulu dan disepakati bersama. Kartini (2002) mendefinisikan kinerja sebagai kinerja yang dapat dicapai oleh seseorang atau kelompok orang dalam suatu organisasi sesuai dengan wewenang dan tanggung jawab masing-masing dalam rangka upaya mencapaitujuan organisasi bersangkutan secara legal, tidak melanggar hukum dan sesuai dengan moral dan etika.

Armstrong dan Baron (1998)

Mendefinisikan Bahwa kinerja merupakan hasil pekerjaan yang mempunyai hubungan kuat dengan tujuan strategis organisasi, kepuasan konsumen, dan memberikan kontribusi pada ekonomi.Kinerja karyawan muncul ketika mengukur keberhasilan seseorang atau kelompok dalam melaksanakan tugastugasnya. Pada saat tersebut dapat menjadi tolak ukur pemimpin ketika ingin menilai terhadap penyelesaian tugas yang diberikan pimpinan.

Dalam pelaksanaan kegiatan organisasi, ada hal penting yang perlu 
e-ISSN 2620-5866

Volume 3. No.1 April 2020 (40-58)

Doi 10.30596/liabilities.v3i1.4581

dilakukan pimpinan yaitu mengukur kinerja karyawan dengan tujuan untuk mengetahui apakah kinerja karyawan mengalami peningkatan atau mengalami penurunan. Pengukuran kinerja dalam organisasi perlu dilakukan, karena dengan dilakukannya pengukuran terhadap karyawan, pimpinan atau pihak manajemen dapat mengetahui kinerja karyawan yang ada didalam organisasinya.Hasil penilaian kinerja karyawan digunakan perusahaan untuk mengambil kebijakan berkenaan dengan:

a. Promosi: adalah mutasi yang memperbesar kewenangan dan tanggung jawab karyawan ke jabatan lain yang lebih tinggi didalam didalam suatu organisasi.Karyawan yang mendapat promosi adalah karyawan yang memiliki kinerja yang baik, perusahaan memberikan promosi bertujuan untuk merangsang karyawannya agar lebih bergairah dalam bekerja, berdisiplin tinggi dan dapat meningkatkan kinerjanya.

b. Mutasi: didefinisikan sebagai suatu perubahan posisi/jabatan/tempat/pekerjaan yang dilakukan secara horizontal maupun vertical (promosi dan demosi) didalam satu organisasi yang pada dasarnya merupakan salah satu fungsi pengembangan karyawan, karena tujuannya meningkatkan efisiensi dan efektifitas kerja dalam perusahaan tersebut. Mutasi merupakan cara untuk menempatkan karyawan pada posisi yang tepat, agar lebih termotivasi dalam bekerja dan dapat meningkatkan kinerjanya.

c. Demosi: Adalah suatu perpindahan karyawan dalam suatu organisasi dari satu posisi keposisi lain yang lebih rendah baik posisi, jabatan maupun kewenangannya dan melibatkan juga penurunan status, maupun gajinya. Demosi dilakukan untuk melindungi organisasi dari penempatan karyawan yang tidak sesuai dan merupakan sebuah hukuman bagi karyawan yang memiliki kinerja dibawah standar.

Beberapa cara yang dapat dilakukan untuk mengukur kinerja, seperti yang dikemukakan oleh Rivai (2005) yaitu sebagai berikut:

1. Melakukan pengukuran dengan cara perbandingan antara kinerja nyata dengan kinerja yang direncanakan.

2. Melakukan pengukuran dengan cara perbandingan antara kinerja nyata dengan hasil (sasaran) yang diharapkan.

3. Melakukan pengukuran dengan cara perbandingan antara kinerja nyata tahun ini dengan tahun-tahun sebelumnya.

4. Melakukan pengukuran dengan cara perbandingan kinerja suatu perusahaan dengan perusahaan lain yang unggul dibidangnya.

5. Melakukan pengukuran dengan cara perbandingan capaian tahun berjalan dengan rancana dalam (dua, tiga, empat, atau lima tahun) pencapaian.

Ukuran secara kualitatif dan kuantitatif yang menunjukkan tingkatan pencapaian suatu sasaran atau tujuan yang telah ditetapkan merupakan sesuatu yang dapat dihitung serta digunakan sebagai dasar untuk menilai atau melihat bahwa kinerja setiap hari dalam perusahaan dan perseorangan terus mengalami peningkatan sesuai dengan rencana yang telah ditetapkan. Dari metode-metode penilaian 
e-ISSN 2620-5866

Volume 3. No.1 April 2020 (40-58)

Doi 10.30596/liabilities.v3i1.4581

kinerja seperti yang dikemukakan diatas dapat diambil kesimpulan bahwa metode penilaian kinerja karyawan sangat dibutuhkan oleh perusahaan. Oleh karena ketika perusahaan menilai atau mengukur melalui skala perbandingan kinerja pada tahun lalu dan pada saat ini apakah kinerja karyawan mengalami peningkatan atau sebaliknya mengalami penurunan. Metode penilaian kinerja merupakan salah satu langkah yang diambil ketika perusahaan ingin mempromosikan karyawan yang mengalami peningkatan kinerjanya ataupun dampak yang lebih buruk adalah memberhentikan karyawan pada saat kinerjanya menurun dan dianggap karyawan tersebut sudah tidak lagi memberikan kontribusi dalam usaha memajukan perusahaan.

Lebih jauh Mathis (2001) menambahkan bahwa kinerja pegawai adalah yang mempengaruhi seberapa banyak mereka memberi kontribusi kepada organisasi yang antara lain termasuk :

1) Kuantitas kerja : Volume kerja yang dihasilkan dibawah kondisi normal

2) Kualitas kerja : Kerapian, ketelitian, dan keterkaitan hasil dengan tidak mengabaikan volume pekerjaan.

3) Pemanfaatan waktu : Penggunaan masa kerja yang disesuaikan dengan kebijaksanaan perusahaan.

4) Kerjasama : Kemampuan menangani hubungan dalam pekerjaan.

Berdasarkan keseluruhan definisi ini dapat dilihat bahwasannya kinerja karyawan ini adalah merupakan output dari penggabungan faktor-faktor penting yakni kemampuan dan minat, penerimaan seorang pekerja. Semakin tinggi faktor-faktor ini, maka semakin besar kinerja karyawan yang bersangkutan.

Dalam hal penilaian kinerja dapat memberi manfaat seperti yang dikemukakan oleh Handoko diantaranya: Keputusan-keputusan penempatan, Promosi dan transfer biasanya didasarkan atas prestasi kerja atau kinerja masa lalu atau antisipasinya. Perencanaan kebutuhan latihan dan pengembangan, Prestasi kerja atau kinerja yang jelek mungkin menunjukan perlunya latihan. Demikian pula sebaliknya, kinerja yangbaik mencerminkan potensi yang harus dikembangkan. Perbaikan prestasi kerja atau kinerja, Umpan balik pelaksanaan kerja memungkinkan karyawan, manajer dan departemen personalia dapat memperbaiki kegiatan-kegiatan mereka untuk meningkatkan prestasi.

Penyesuaian-penyesuaian

kompensasi, Evaluasi prestasi kerja membantu para pengambil keputusan dalam menentukan kenaikan upah, pemberian bonus dan bentuk kompensasi lainnya. Melihat ketidak akuratan informasional, Prestasi kerja yang jelek menunjukan kesalahankesalahan dalam informasi analisis jabatan, rencana sumber daya manusia, atau komponen-komponen lain dari sistem informasi manajemen personalia, menggantungkan pada informasi yang tidak akurat dapat menyebabkan keputusan-keputusan personalia tidak tepat.

Mendeteksi kesalahankesalahan desain pekerjaan, Prestasi 
e-ISSN 2620-5866

Volume 3. No.1 April 2020 (40-58)

Doi 10.30596/liabilities.v3i1.4581

kerja yang jelek merupakan tanda kesalahan dalam pekerjaan. Penilaian pretasi membantu diagnosa kesalahan-kesalahan tersebut.

Perencanaan dan penembangan karir. Umpan balik prestasi mengarahkan keputusan-keputusan karir, yaitu tentang jalur karir tertentu yang harus diteliti. Mendeteksi penyimpangan proses staffing Prestasi kerja yang baik atau buruk adalah mencerminkan kekuatan atau kelemahan prosedur staffing departemen personalia. Melihat tantangan-tantangan eksternal, Kadang-kadang prestasi seseorang dipengaruhi oleh faktor-faktor di luar lingkungan kerja, seperti keluarga, kesehatan, dan masalah pribadi lainnya. Menjamin kesempatan kerja yang adil. Penilaian prestasi kerja yang akurat akan menjamin keputusan-keputusan penempatan internal diambil tanpa diskriminasi.

Dari beberapa teori yang diungkapkan di atas dapat diambil kesimpulan bahwa manfaat penilaian kinerja dapat mengetahui kinerja dari karyawan tiap tahunnya baik atau buruknya, berguna juga dalam memberikan kompensasi atau untuk jenjang karir pada perusahaan baik pula untuk mengetahui kesalahan dari karyawan yang dapat digunakan untuk meningkatkan prestasi kerja baik masalah intern maupun ekstern yang dapat menghambat laju perkembangan perusahaan.

Penilaian kinerja juga bermanfaat dalam mengevaluasi kinerja, produktivitas organisasi serta unit kerja pada umumnya kemudian dapat pula mengetahui kinerja dari tiap-tiap individu pegawai pada tiap jabatan sehingga mengetahui penurunan atau peningkatan sehingga ketika dalam memberikan upah, promosi jabatan tidak ada yang merasa diperlakukan tidak adil. manfaat penilaian kinerja dapat pula untuk mengetahui kondisi keuangan personalia maupun pegawai sert pelatihan pengembangan yang berguna bagi pegawai ketika melaksanakan tugas yang telah diberikan pelatihan dan pengembangn pegawai berguna bagi individu pegawai maupun bagi perusahaan.

\section{Gaya Kepemimpinan}

$\begin{array}{lrr}\text { Para ahli di bidang } \\ \text { manajemen banyak } & \begin{array}{r}\text { menyajikan } \\ \text { literatur-literatur }\end{array} & \text { tentang }\end{array}$ kepemimpinan dari hasil penelitian dan penelaahan mendalam, dan melahirkan berbagai teori kepemimpinan. Teori kepemimpinan banyak mengkaji masalah arti penting kepemimpinan, kepemimpinan, efektivitas kepemimpinan, perilaku kepemimpinan dan segala hal yang berkaitan dengan aktivitas kepemimpinan.Kepemimpinan

merupakan salah satu fenomena yang paling mudah untuk diobservasi, namun menjadi salah satu hal yang paling sulit untuk dipahami. Robbins (2001) memberikan pemahaman dengan mendefenisikan kepemimpinan sebagai "sebuah hubungan yang saling mempengaruhi antara pemimpin dan pengikut (bawahan) yang menginginkan perubahan nyata yang mencerminkan tujuan bersama".

Kepemimpinan adalah usaha seseorang untuk mengubah perilaku pihak lain, apalagi anggota-anggota tersebut secara nyata nampak berubah kearah yang baik maka kepemimpinannya dinyatakan 
e-ISSN 2620-5866

Volume 3. No.1 April 2020 (40-58)

Doi 10.30596/liabilities.v3i1.4581

berhasil. Kepemimpinan adalah kemampuan untuk mempengaruhi, menggerakan, dan mengarahkan suatu tindakan pada diri seseorang atau sekelompok orang untuk mencapai tujuan tertentu pada situasi tertentu, kepemimpinan merupakan salah satu aspek manajerial dalam kehidupan oganisasi yang merupakan posisi kunci karena kepemimpinan seorang manajer berperan sebagai penyelaras dalam proses kerja sama antar manusia dalam organisasinya.

\section{Menurut}

Stoner

kepemimpinan dapat didefinisikan sebagai suatu proses pengarahan dan pemberian pengaruh pada kegiatankegiatan dari sekelompok anggota yang saling berhubungan tugasnya. Selanjutnya Robert Tannembaum, Irving R, Weschler, dan Fred Massarik mendefinisikan kepemimpinan sebagai pengaruh perseorangan dalam situasi tertentu secara langsung melalui proses komunikasi untuk mencapai tujuantujuan umum dan khusus. Hal yang sama dikemukakan oleh stogdill bahwa kepemimpinan atau leadership adalah proses mempengaruhi kegiatankegiatankelompok yang terorganisir dalam usaha-usaha menentukan tujuan dan mencapainya.

Selain itu definisi yang dikemukan oleh Bennis tentang kepemimpinan (leadership) adalah "the prosses by which an agent induces a subordinate to behave in a desired manner". Kepemimpinan adalah proses dimana seorang agen menyebabkan seorang bawahan bertingkah laku menurut satu cara tertentu. Segala kegiatan, tindakan atau keputusan yang dilakukan pemimpin sangat berpengaruh terhadap kerja kelompok, artinya apapun tindakan yang dilakukan dapat menurunkan atau pun menaikan produktivitas serta kinerja dari karyawan. Pandjojo (2000) mendefinisikan pemimpin adalah "leadership is the process of influencing the activities of an individual or group in effort toward goal achievment in a given situation". Kepemimpinan adalah proses mempengaruhi aktivitas seseorang atau suatu kelompok dalam upayamencapai tujuan dalam situasi tertentu.

Setelah menguraikan pengertian tentang kepemimpinan, selanjutnya menjelaskan definisi gaya kepemimpinan. Gaya kepemimpinan merupakan aspek penting untuk mencapai dan meningkatkan keberhasilan kepemimpinan seseorang dalam suatu organisasi. Gaya kepemimpinan merupakan norma perilaku yang digunakan oleh seseorang pada saat orang tersebut mencoba mempengaruhi perilaku orang lain seperti yang ia lihat.Selanjutnya dikemukakan bahwa gaya kepemimpinan dapat pula diartikan sebagai norma perilaku yang digunakan seseorang pada saat orang tersebut mencoba mempengaruhi perilaku orang lainseperti yang ia lihat. Dalam hal ini usaha menselaraskan persepsi diantara orang yang akan mempengaruhi perilaku dengan yang akan dipengaruhi menjadi amat penting kedudukannya.

Dalam perspektif lain gaya kepemimpinan adapat diartikan sekumpulan ciri yang digunakan pimpinan untuk memengaruhi bawahan agar sasaran organisasi tercapai atau dapat pula dikatakan 
e-ISSN 2620-5866

Volume 3. No.1 April 2020 (40-58)

Doi 10.30596/liabilities.v3i1.4581

bahwa gaya kepemimpinan adalah pola perilaku dan strategi yang disukai dan sering diterapkan oleh seorang pemimpin.Gaya kepemimpinan yang menunjukkan, secara langsung maupun tidak langsung, tentang keyakinan seorang pimpinan terhadap kemampuan bawahannya.Artinya gaya kepemimpinan adalah perilaku dan strategi, sebagai hasil kombinasi dari falsafah, keterampilan, sifat, sikap, yang sering diterapkan seorang pemimpin ketika ia mencoba memengaruhi kinerja bawahannya.

Dari berbagi macam teori yang disebutkan di atas dapat diambil kesimpulan bahwa gaya kepemimpinan adalah suatu usaha yang dilakukan seseorang untuk mempengaruhi bawahan dengan berbagai macam cara/tekniknya masing-masing dan mempunyai kemampuan untuk mempengaruhi, menggerakan, mengarahkan seseorang atau kelompok kearah yang lebih baik dan positif melalui proses yang panjang. Apapun yang diucapkan maupun yang diperbuat oleh pemimpin sangat berpengaruh terhadap kinerja dari karyawan maka dari itu seorang pemimpin harus mahir dalam berkomunikasi sehingga mengetahui kelemahan ataupun kelebihan bawahan disamping itu pemimpin haruslah mempunyai moral dan etika yang baik sehingga akan tercipta hubungan yang harmonis antara pemimpin dengan bawahan dengan demikian kemajuan perusahaan akan tercapai sebagaimana yang telah dicita-citakan bersama. Dalam memimpin perusahaan terdapat 3 model kepemimpinan yang mempengaruhi perilaku individu dalam perusahaan diantaranya adalah model demokrasi, autoritarian, dan laissez-faire:

a. Model Demokrasi, tipe model pemimpin demokrasi sangat membutuhkan masukan-masukan tambahan dari karyawan atau kelompok dalam memutuskan serta memecahkan masalah dan sangat terbuka terhadap idea tau pendapat baru. Tugasnya hanya memimpin dalam rapat/musyawarah dan anggota lain bebas untuk mengungkapkan pendapatnya serta menampung semua pendapat dari anggota kemudian meramunya untuk menemukan suatu solusi atau gagasan yang baik.

b. Model Autotarian (otoriter), dalam tipe model kepemimpinan ini seorang pemimpin merasa bahwa ia memegang kekuasaan/wewenang penuh terhadap apa saja program yang dibuat juga ia tidak memerlukan masukan atau usulan serta musyawarah terlebih dahulu setelah itu anggota wajib mentaati serta mematuhi program yang telah dibuat. c. Model Laissezfaire (liberal) dalam tipe model pemimpin seperti ini dalam memimpin anggota/bawahannya hanya memutuskan kebijakan penting serta memberikan informasi dan fasilitas yang dibutuhkan karyawan dia tidak mengajarkan bagaimana cara mengerjakan pekerjaannya akibatnya pekerjaan dilaksanakan sesuai dengan kemampuan yang dimiliki hasil dari pekerjaan tinggi/baik atau pun bisa rendah/buruk.

\begin{tabular}{lcr}
\multicolumn{1}{c}{ Hersey dan } & Blanchard \\
menjabarkan & bahwa & model \\
kepemimpinan & dibaginya & kedalam \\
empat gaya diantaranya: &
\end{tabular}

a. Direktif, pemimpin banyak 
e-ISSN 2620-5866

Volume 3. No.1 April 2020 (40-58)

Doi 10.30596/liabilities.v3i1.4581

memberi pengarahan dan sedikit memberi dukungan akibatnya kemampuan karyawan tinggi dan kemauannya dalam bekerja menjadi rendah. Kemampuan karyawan tinggi dikarenakan karyawan diberikan tekanan terhadap tugas pekerjaanya yang mengakibatkan adanya unsur keterpaksaan bukan dari kesadaran pribadi karyawan dalam menyelesaikan tugasnya itu.

b. Melatih, pemimpin banyak mengarahkan dan banyak juga mendukung akibatnya kemampuan karyawan tinggi dan kemauannya dalam bekerja menjadi tinggi. Artinya pemimpin memberikan pelatihan kepada karyawan terlebih dahulu terhadap tugas-tugas yang harus diselesaikan dan banyak memberikan petunjuk kepada karyawan ketika karyawan menemukan masalah dalam melaksanakan pekerjaannya.

c. Supportif, pemimpin banyak mendukung tapi kurang memberikan arahan akibatnya kemampuan rendah dan kemauan dalam bekerja tinggi. Artinya pemimpin banyak memberikan masukan atau dukungan moral akan tetapi tidak memberikan petunjuk pengerjaan agar tugas-tugas yang diberikan dapat diselesaikan dengan cepat.

d. Mendelegasikan, pemimpin kurang memberi dukungan dan juga kurang dalam hal memberikan pengarahan akibatnya kemampuan rendah dan kemauannya dalam bekerja rendah. Artinya pemimpin tidak melakukan kedua hal yangwajib diberikan kepada karyawan baik dukungan moral maupun petunjuk pengerjaan tugas yang dampaknya karyawan menjadi enggan untuk menyelesaikan tugasnya dengan tepat waktu.

Menurut Soewarno ada Tiga tipe dasar pemimpin sebagai bentukbentuk proses pemecahan masalah dan mengambil keputusan, adalah sebagai berikut:

a. Pemimpin Otokratis

Pemimpin yang bersifat otokratis memperlihatkan ciri-ciri sebagai berikut: perintah-perintahnya harus selalu diikuti, menentukan kebijaksanaan karyawan tanpa sepengetahuan mereka, tidak memberikan penjelasan secara terperinci tentang rencana yang akan datang, tetapi sekedar mengatakan kepada anggotanya tentang langkah-langkah yang dibuat bawahan/karyawan wajib menjalankannya, Memberikan pujian kepada meraka yang selalu menurut kehendaknya dan melontarkan kritik kepada mereka yang tidak mengikuti kehendaknya, Selalu menjaga jarak dengan anggota sehingga terlihat kerenggangan hubungan antara pemimpin dengan anggota .

b. Pemimpin demokratis

Pemimpin seperti ini sangat menjunjung rasa kebersamaan dengan anggota karyawan. pemimpin hanya memberikan perintah setelah mengadakan musyawarah dahulu dengan anggotanya dan mengetahui bahwa anggota dapat menerima kebijakan yang akan dibuat, Pemimpin tidak akan meminta anggotanya mengerjakan sesuatu pekerjaan tanpa terlebih dahulu memberitahukan rencana yang akan mereka lakukan baik atau buruk benaratau salah merupakan tanggung jawab yang diemban bersama-sama, 
e-ISSN 2620-5866

Volume 3. No.1 April 2020 (40-58)

Doi 10.30596/liabilities.v3i1.4581

Dalam pelaksanaannya pemimpin demokratis dapat menciptakan hubungan yang baik antara pemimpin dengan anggota.

c. Pemimpin Liberal atau LaissezFaire

Pemimpin liberal yaitu pemimpin memberikan kebebasan tanpa pengendalian dalam kegiatan kepemimpinannya, Pemimpin tidak memimpin atau mengendalikan bawahan sepenuhnya dan tidak pernah ikut serta dengan bawahannya ketika itu pemimpin hanya memberikan mengawasi saja karena pemimpin seperti ini beranggapan antara keduanya mempunyai tugas dan kapasitasnya masing-masing.

\section{Hubungan Gaya Kepemimpinan dengan Kinerja Karyawan}

Seperti kita ketahui bahwa gaya kepamimpinan merupakan suatu pola tingkah laku yang disukai pemimpin dalam peroses mengarahkan dan mempengaruhi pekerja. Setiap pemimpin mempunyai gaya kepemimpinanya sendiri. Pemimpin dapat melaksanakan pekerjaannya dengan baik apabila pemimpin tersebut dapat menyesuaikan dengan situasi kerja yang dihadapinya, sedangkan jika karyawan kurang berprestasi maka sulit bagi organisasi perusahaan dapat memperoleh hasil yang baik.

Hal ini mengharuskan pemimpin menggunakan kewenangan untuk mengubah sikap dan perilaku karyawan supaya mau berkerja giat serta berkeinginan mencapai hasil optimal. Untuk mempengaruhi sikap dan perilaku karyawan yang diinginkan, pemimpin harus meningkatkan kinerja karyawan yang diinginkan, pemimpin harus meningkatkan kinerja karyawan supaya dapat mendorong karyawan mau bekerja dengan baik. Keberhasilan perusahaan pada dasarnya ditopang oleh kepemimpinannya yang efektif, dimana dengan kepemimpinannya itu dia dapat mempengaruhi bawahannya untuk membangkitkan motivasi kerja mereka agar berpartisipasi terhadap tujuan bersama. Pemimpin merupakan orang yang menerapkan prinsip dan teknik yang memastikan motivasi, disiplin, dan produktivitas jika bekerjasama dengan orang, tugas, dan situasi agar dapat mencapai sasaran perusahaan.

Mengerti dan mengetahui hal-hal yang dapat membangkitkan motivasi dalam diri seseorang merupakan kunci untuk mengatur orang lain. Tugas pemimpin adalah mengidentifikasi dan memotivasi dengan baik, yang pada akhirnya akan meningkatkan kinerja karyawan. Keadaan ini merupakan suatu tantangan bagi seorang pemimpin untuk dapat menciptakan iklim organisasi yang dapat meningkatkan kinerja karyawan yang tinggi. Dari uraian diatas dapat disimpulkan bahwa gaya kepemimpinan sangat mempengaruhi kinerja karyawan.

\section{METODE PENELITIAN}

Untuk memberikan gambaran yang jelas dan memudahkan pelaksanaan penelitian ini, maka perlu diberikan materi penelitian yang akan diteliti sebagai dasar dalam menyusun kuesioner penelitian, materi yang akan dibahas dalam penelitian ini terkait dengan Gaya Kepemimpinan dan Kinerja Karyawan. 
e-ISSN 2620-5866

Volume 3. No.1 April 2020 (40-58)

Doi 10.30596/liabilities.v3i1.4581

1. Variabel dependen dalam penelitian ini adalah :

Kinerja merupakan perilaku nyata yang ditampilkan setiap orang sebagai kinerja yang dihasilkan oleh karyawan sesuai dengan perannya dalam perusahaan.

2. Variabel Independen dalam penelitian ini adalah :

Gaya kepemimpinan adalah usaha yang dilakukan seseorang untuk mempengaruhi bawahan dengan berbagai macam cara/tekniknya masing-masing dan mempunyai kemampuan untuk mempengaruhi, menggerakan, mengarahkan seseorang atau kelompok kearah yang lebih baik dan positif melalui proses yang panjang.

\section{Teknik Pengumpulan Data}

Teknik pengumpulan data dalam penelitian ini dilakukan melalui wawancara, kuesioner dan studi dokumentasi. Teknik pengumpulan data yang digunakan dalam penelitian ini sebagai berikut :

a. Wawancara yaitu pengumpulan data dengan cara pengamatan langsung pada objek yang deteliti, atau dapat dirumuskan sebagai proses pencatatan pola perilaku subjek (orang) atau kejadian sistematik dengan pertanyaan atau komunikasi dengan individu yang diteliti.

b. Angket/ kuesioner yaitu teknik pengumpulan data yang digunakan dengan cara menyebarkan daftar pertanyaan kepada responden penelitian. Setiap jawaban pertanyaan berkaitan dengan kepemimpinan, etos kerja, disiplin kerja dan kinerja serta diberikan skor sesuai dengan masingmasing skala pengukuran. Pengukuran dari variabel-variabel penelitian ini sendiri menggunakan skala Likert. Skala Likert digunakan untuk mengukur sikap, pendapat dan persepsi seseorang atau kelompok orang tentang fenomena sosial.

c. Studi Dokumentasi dilakukan dengan mengumpulkan dan mempelajari data atau dokumen yang mendukung penelitian yang diperoleh dari buku-buku, dokumen, jurnal dan arsip-arsip yang berkaitan dengan penelitian.

\section{HASIL PENELITIAN}

\section{Uji Asumsi Klasik}

Pengujian asumsi klasik yang digunakan dalam penelitian ini meliputi uji normalitas, uji multikolinearitas, dan uji heteroskedastisitas.

\section{a. Uji Normalitas}

Pada penelitian ini uji normalitas residual dapat dilakukan dengan uji statistik non-parametrik KolmogorovSmirnov (K-S), dan Normal P-P Plot. Uji K-S dilakukan dengan membuat hipotesis :

$\mathrm{H}_{0}$ : Data residual terdistribusi normal $\mathrm{H}_{1}$ : Data residual tidak terdistribusi normal

Untuk menentukannya maka kriterianya adalah $\mathrm{H}_{0}$ diterima apabila nilai signifikansi (Asymp. Sig) > 0,05 $\mathrm{H}_{1}$ diterima apabila nilai signifikansi (Asymp. Sig) <0,05 Hasil Uuntuk normalitas data dapat dilihat sebagai berikut:

Tabel 4.6 Hasil Uji Normalitas One-Sample Kolmogorov-Smirnov Test

\begin{tabular}{|lr|r|}
\hline & & \multicolumn{2}{|l|}{$\begin{array}{l}\text { Rnstandardized } \\
\text { Residual }\end{array}$} \\
\hline $\mathrm{N}$ & & 36 \\
Normal Parameters & & \\
& Mean & .0000000 \\
& Std. & 4.07400010 \\
Most Extreme & Deviation & .051 \\
\hline
\end{tabular}


e-ISSN 2620-5866

Volume 3. No.1 April 2020 (40-58)

Doi 10.30596/liabilities.v3i1.4581

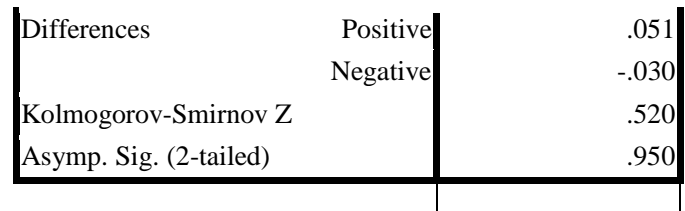

a. Test distribution is Normal.

Berdasarkan Tabel 4.6 dapat diketahui bahwa nilai signifikansi Kolmogorov-Smirnov $(K-S)$ adalah 0,950 maka dapat disimpulkan bahwa data variabel terdistribusi normal karena signifikansi> 0,05.Pengujian normalitas data juga dapat diketahui dengan melihat gambar grafik dan kurva distribusi normal. Data akan terdistribusi secara normal jika nilai probabilitas yang diharapkan adalah sama dengan nilai probabilitas harapan dan probabilitas pengamatan ditunjukan dengan garis diagonal yang merupakan perpotongan antara garis probabilitas harapan dan probabilitas pengamatan. Berikut ini merupakan pengujian hasil normalitas data dalam bentuk grafik hitogram dan kurva P-P Plots seperti yang terlihat pada gambar 4.1 berikut:

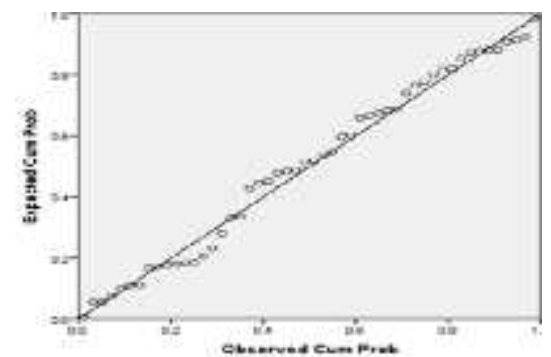

Gambar 4.1 Histogram

Berdasarkan gambar grafik histogram pada gambar 4.1 dapat disimpulkan bahwa data telah berdistribusi secara normal. Hal ini dapat dilihat pada data yang mengikuti garis diagonal membentuk lonceng berada di tengah-tengah.

Histagerem

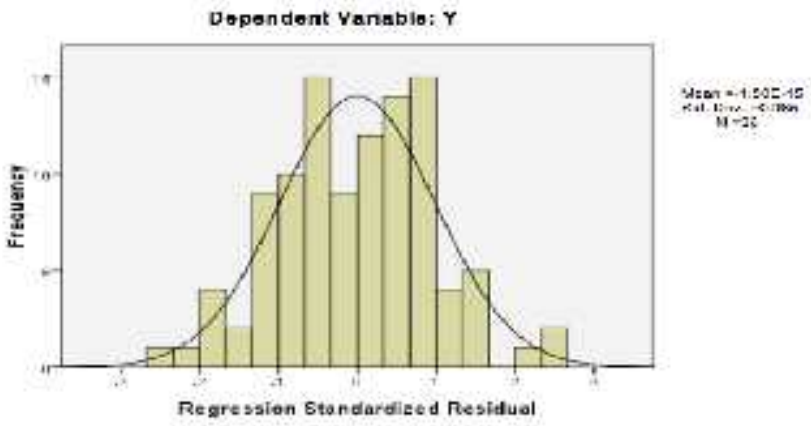

Gambar 4.2 Normal P-Plot

Berdasarkan Gambar 4.2 dapat disimpulkan bahwa grafik normal P-P Plot tersebar sepanjang garis diagonal. Grafik ini menunjukkan bahwa data terdistribusi normal.

\section{Uji Multikolinearitas}

Pengujian multikolinearitas dilakukan dengan menggunakan Variance Inflation Factor (VIF). Data dikatakan tidak mengalami multikolinearitas apabila nilai Tolerance $\geq 0,10$ dan nilai VIF $\leq 10$. Hasil uji multikolinearitas dapat dilihat pada Tabel 4.8.

Tabel 4.7 Hasil Uji

Multikolinearitas

\begin{tabular}{|ll|l|l|}
\hline \multicolumn{2}{|c|}{} & \multicolumn{3}{|l|}{$\begin{array}{l}\text { Collinearity } \\
\text { Statistics }\end{array}$} \\
\cline { 3 - 4 } & \multicolumn{2}{|l|}{ Tolerance } & VIF \\
\hline 1 & $\begin{array}{l}\text { (Constant) } \\
\text { Gaya } \\
\text { Kepemimpinan } \\
\text { Direktif }\end{array}$ & & \\
\hline
\end{tabular}

a. Dependent Variable: Kinerja Karyawan

Berdasarkan Tabel 4.7

menunjukkan bahwa seluruh variabel independen memiliki Tolerance $\geq$ 0,10 dan nilai VIF $\leq 10$ sehingga data penelitian ini tidak mengalami multikolinearitas. 
e-ISSN 2620-5866

Volume 3. No.1 April 2020 (40-58)

Doi 10.30596/liabilities.v3i1.4581

\section{Uji Heterokedastisitas}

Model regresi yang baik adalah yang homoskodesitas atau tidak terjadi heteroskedastisitas.Uji ini dilakukan dengan menggunakan analisis grafik scatterplot antara nilai prediksi variabel terikat ZPRED dengan residualnya SPRESID. Dari grafik scatterplot terlihat bahwa titiktitik menyebar secara acak di atas maupun di bawah angka 0 pada sumbu Y. Hal ini dapat disimpulkan bahwa tidak terjadi heteroskedastisitas pada model regresi. Scatterplot penelitian ini dapat ditunjukkan pada Gambar berikut:

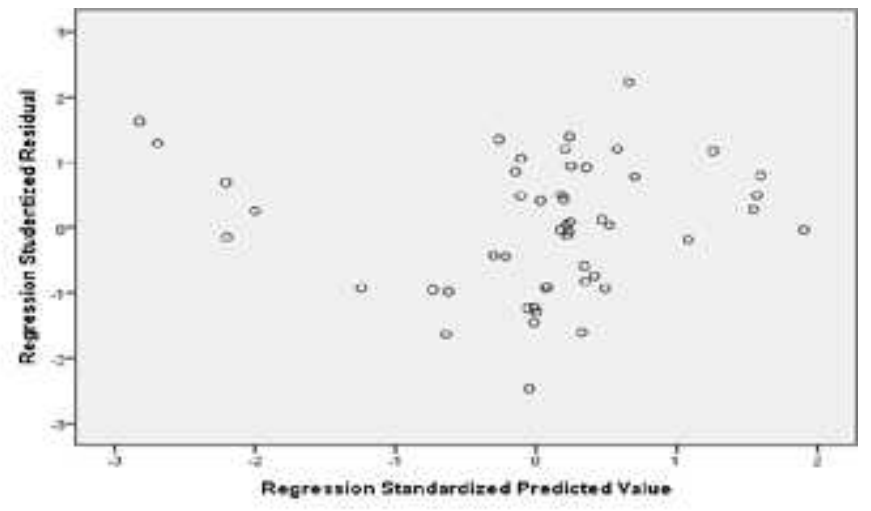

atas maupun dibawah angka 0 (nol) pada sumbu Y sehingga dapat disimpulkan bahwa tidak terjadi heteroskedastisitas pada model regresi.

\section{Uji Hipotesis}

\section{Analisis Regresi Linear Sederhana}

Untuk mengetahui pengaruh variabel independen secara parsial dan simultan berpengaruh signifikan terhadap variabel dependen, maka analisa statistik yang digunakan adalah dengan menggunakan analisis regresi berganda. Hasil analisis linear berganda dapat dilihat pada Tabel 4.8.
Tabel 4.8 Hasil Analisis Regresi Linear Sederhana Coefficients $^{\mathrm{a}}$

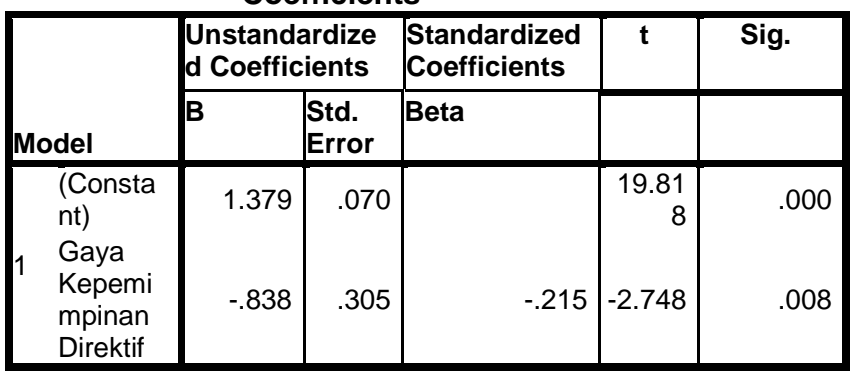

a. Dependent Variable: Kinerja Karyawan

Dari hasil regresi linear sederhana, maka dapat disusun persamaan regresi sebagai berikut:

$$
\mathrm{Y}=\mathbf{1 , 3 7 9} \text { - 0,838 X }
$$

Berdasarkan

persamaan

regresi terlihat bahwa:

1) Nilai konstanta sebesar 1,379 artinya bahwa variabel dependen akan bernilai sebagaimana konstanta meskipun variabel independen bernilai nol.

2) Nilai koefesien untuk variabel $X$ (Gaya Kepemimpinan Direktif) adalah sebesar $-0,838$ artinya setiap kenaikan variabel gaya kepemimpinan direktif sebesar 1 satuanmaka variable kinerja karyawan akan turun sebesar 0,838 kali.

\section{Uji Parsial (Uji t)}

Uji statistik $\mathrm{t}$ pada dasarnya menunjukkan seberapa jauh satu variabel independen secara individual dalam menerangkan variasi variabel dependen. Hasil uji $\mathrm{t}$ dapat dilihat pada Tabel 4.8. Melalui Tabel dapat diketahui bahwa nilai t-hitung variabel gaya kepemimpinan direktif senilai 2,748 lebih besar apabila dibandingkan dengan t-tabel dengan df $=36-2=34$ pada taraf signifikansi $5 \%$ yaitu 1,691 sehingga Ho ditolak dan $\mathrm{Ha}$ diterima. Adapun variabel gaya kepemimpinan direktif menunjukkan nilai signifikansi 0,008 $(\mathrm{Sig}=0,000<0,05)$ sehingga secara 
e-ISSN 2620-5866

Volume 3. No.1 April 2020 (40-58)

Doi 10.30596/liabilities.v3i1.4581

parsial gaya kepemimpinan direktif berpengaruh signifikan terhadap kinerja karyawan Departemen Pengadaan PT Inalum (Persero).

Koefisien Determinasi $\left(\mathbf{R}^{2}\right)$

Koefisien determinasi $\left(\mathrm{R}^{2}\right)$ digunakan untuk mengetahui seberapa besar variabel independen dapat menjelaskan variabel dependen. Hasil uji koefisien determinasi $\left(\mathrm{R}^{2}\right)$ dapat dilihat pada Tabel 4.9.

Tabel 4.9 Hasil Koefisien Determinasi

\begin{tabular}{|c|c|c|c|c|c|}
\hline Model & $\mathbf{R}$ & $\begin{array}{c}\text { R } \\
\text { Square }\end{array}$ & $\begin{array}{l}\text { Adjusted } \\
\text { R Square }\end{array}$ & $\begin{array}{c}\text { Std. Error } \\
\text { of the } \\
\text { Estimate }\end{array}$ & $\begin{array}{l}\text { Durbin- } \\
\text { Watson }\end{array}$ \\
\hline 1 & $.846^{\mathrm{a}}$ & .615 & .603 & .25886 & 1.203 \\
\hline
\end{tabular}

Dari tabel 4.9 dapat diketahui bahwa nilai koefisien (R) sebesar 0,846 menunjukkan besarnya hubungan antara variabel, dengan koefisien determinasi ( $R$ square) sebesar 0,615 atau $61,5 \%$. Hal ini berarti gaya kepemimpinan direktif dapat menjelaskan variabel kinerja karyawan sebesar $61,5 \%$. Sedangkan sisanya $38,5 \%$ dijelaskan oleh variabel lain diluar model estimasi ini.

\section{Pembahasan Hasil Penelitian}

Berdasarkan hasil pengujian variabel gaya kepemimpinan direktif terhadap kinerja karyawan menggunakan uji $\mathrm{t}$, diperoleh hasil bahwa variabel gaya kepemimpinan direktif $\left(\mathrm{X}_{1}\right)$ memiliki nilai t-hitung lebih besar dibadingkan t-tabel $(2,478$ $>1,691)$ dengan nilai signifikansi 0,008 (Sig $=0,008<0,05)$.

Hal ini menunjukkan bahwa gaya kepemimpinan direktifberpengaruh signifikan terhadap keputusan menjadi karyawan. Hasil pengujian menerima hipotesis parsial. Secara teoritis, hal ini sesuai bahwaemimpin yang terdapat pada organisasi harus memiliki kelebihan-kelebihan dibandingkan dengan bawahannya, sehingga dapat menunjukkan kepada bawahannya untuk bergerak, bergiat, berdaya upaya yang tinggi untuk mencapai tujuan-tujuan yang telah ditetapkan.

Hasil inimendukung penelitian olehManshur (2010) dan Cahyono (2004). Kedua penelitian tersebut mengungkapkan bahwa gaya kepemimpinan berpengaruh terhadap kinerja karyawan. Implikasi dari hasil penelitian ini yaitu gaya kepemimpinan merupakan faktor penentu tinggi rendahnya gaya kepemimpinan karyawan. Namun demikian, perlu dicermati bahwa arah pengaruh hubungan dalam hasil penelitian ini berupa negatif $(-2,478)$. Ini berarti semakin direktif gaya kepemimpinan yang dilakukan pada Departemen Pengadaan PT Inalum (Persero), akan menyebabkan penurunan kinerja karyawan. Oleh karena itu, PT Inalum (Persero) perlu melakukan upaya perubahan paradigma dan model kepemimpinan, misalnya dengan pendekatan gaya kepemimpinan transformasional maupun gaya kepemimpinan demokratis. Hal ini diharapkan mampu selaras dalam meningkatkan kinerja karyawan.

\section{KESIMPULAN DAN SARAN Kesimpulan}

Bahwa gaya kepemimpinan direktif berpengaruh signifikan terhadap kinerja karyawan pada Departemen Pengadaan PT Inalum (Persero). Hal ini dibuktikan dari hasil pengujian parsial yang menunjukkan bahwa 
variabel gaya kepemimpinan direktif (X) memiliki nilai t-hitung lebih besar dibadingkan $\mathrm{t}$-tabel $(2,748>1,691)$ dengan nilai signifikansi $0,008(\mathrm{Sig}=$ $0,008<0,05)$.

\section{Saran}

Adapun saran yang atas dasar kesimpulan penelitian diatas, adalah sebagai berikut:

1. PT Inalum (Persero) perlu melakukan upaya perubahan paradigma dan model kepemimpinan, misalnya dengan pendekatan gaya kepemimpinan transformasional maupun gaya kepemimpinan demokratis. Hal tersebut dapat diwujudkan melalui program pendidikan dan pelatihan kepemimpinan bagi karyawan,

2. Peneliti selanjutnya diharapkan menambah sampel data dengan memperpanjang periode pengamatan.

\section{DAFTAR PUSTAKA}

Arikunto, Suharsimi. Prosedur Penelitian, Rineka Cipta : Bandung, 2006.

Bawdy El, Tarek A., Manal Bassiouny. Employee

Engagement as a Mediator between Transformational Leadership and Intention to Quit. Journal of Management,12. 2014

Dessler, Gary. Manajemen sumber daya manusia jilid 2. Jakarta: Gramedia, 2005.

Dharma, Surya. Manajemen Kinerja.Yogyakarta:Pustaka Pelajar. 2010.

Ghozali, Imam. Aplikasi Analisis Multivariate Dengan Program SPSS Edisi Ketiga Badan Penerbit Universitas
Diponegoro : Semarang. 2007. Hasibuan, S.P. Malayu. Manajemen Sumber Daya Manusia, , Jakarta : Bumi Aksara, 2003.

Henry Simamora. Manajemen Sumber Daya Manusia. Yogyakarta: STIE YKPN. 2004.

Nur, Indriantoro dan Bambang Supomo. Metode Penelitian Bisnis. Edisi I. BPFE. Yogyakarta. 2002.

Kartini, Kartono. Pemimpin dan Kepimimpinan-Apakah

Pemimpin yang Abnormal itu?. Edisi Pertama, Cetakan Ketigabelas, PT Raja Grafindo Persada. 2002

Kuncoro,Mudrajad. Metode Riset untuk Bisnis dan Ekonomi Edisi 4. Jakarta: Erlangga. 2013.

Lako, Andreas. Kepemimpinan dan Kinerja Organisasi : Isu, Teori dan Solusi, Cetakan Pertama, Penerbit Amara Books, Yogyakarta. 2004.

Mangkunegara. Evaluasi Kinerja Sumber Daya Manusia. Bandung : Rafika Aditama. 2005 ,

Manulang, Marihot. Manajemen Personalia, gajah mada university press, 2006

Sekaran, Uma. 2000. Research Methods for business: A Skill Building Approach. Singapore: John Wiley \& Sons, Inc.

Siagian, Sondang.P. Organisasi Kepemimpinan dan perilaku Administrasi, Gunung Agung. Jakarta. 2001.

Suwatno dan Donni Juni P. Manajemen SDM dalam organisasi publik dan bisnis, 
LIABILITIES (JURNAL PENDIDIKAN AKUNTANSI)

e-ISSN 2620-5866

Volume 3. No.1 April 2020 (40-58)

Doi 10.30596/liabilities.v3i1.4581

penerbit alfabeta, Bandung.

2011.

Suharyadi dan Purwanto

S.K..Statistika: Untuk

Ekonomi \& Keuangan

Modern. Jakarta: Salemba

Empat. 2004

Sugiyono. Metode Penelitian Bisnis, Alfabeta, Bandung, 2006.

Syalman, Popy. Pengaruh Gaya Kepemimpinan Path Goal, Kominikasi Internal dan Motivasi Ekstrinsik terhadap Kinerja karyawan Pada UMKM Foto Copy di Wilayah Yogyakarta. Jurnal: Universitas Muhammadiyah Yogyakarta. 2017.

T. Hani, Handokko, Manajemen Personalia dan Sumber daya Manusia, Edisi 2, Penerbit BPFE, Yogyakarta. 2000. 